\title{
The Influence of Organization Culture and Work Motivation on Employee Productivity of Bank BJB Rancaekek Branch
}

\author{
Yudhy $^{1 *}$, Nur'aeni $^{2}$ \\ ${ }^{I}$ Doctoral student, Postgraduate School, UIN Sunan Gunung Jati Bandung, Bandung, Indonesia \\ ${ }^{2,3}$ Faculty of Economics and Islamic Business, Ma 'soem University, Bandung, Indonesia \\ *Corresponding author e-mail address: yudhy.amik@gmail.com
}

\begin{abstract}
This study aimed to learn the influence of organization culture on employee productivity in Bank BJB Syariah Rancaekek Branch, and to know the influence of work motivation on employee productivity in Bank BJB Syariah Rancaekek Branch. The object of study is to know the organization culture at Bank BJB Syariah Rancaekek Branch. The type of study is associative quantitative, the type of data is primary data and use data collection techniques of observations, interviews, questionnaires and literature studies. Sampling technique is census technique with 18 respondents. The result of the study showed that there is significant influence between organization culture on employee productivity in Bank BJB Syariah Rancaekek Branch and organization culture on employee work motivation in Bank BJB Syariah Rancaekek Branch.
\end{abstract}

Keywords: organization culture; work motivation; employee productivity

\section{Introduction}

The development of sharia banking in Indonesia has become the benchmark of the success of the existence of the sharia economy (Suhartanto et al., 2019). Bank Muamalat as the first sharia bank and a pioneer for other sharia banks has already implemented this system amid the rise of conventional banks. Monetary crisis happened in 1998 has sunk conventional banks and many were liquidated due to the failure of its interest systems. Meanwhile, banks that apply sharia system can still able to exist and survive (Suhartanto et al., 2018). Not only that, in the midst of global financial crisis that hit the world in the end of 2008, sharia financial institutions was still stable and gave profits, convenient and securities to their shareholders, securities holders, borrowers, and funders in sharia banks.

Bank BJB Syariah is one of the banks that exist to provide sharia banking product services in Indonesia. At the beginning, BJB Syariah is a division/sharia business unit from PT Bank Pembangunan Daerah Jawa Barat and Banten. This division/unit was established on 20 May 2000 with the purpose of fulfilling the needs of the people of West Java that began to grow the desire to use banking service. As a quite large sharia financial institution, Bank BJB Syariah Rancaekek branch keep trying to provide the 
best service for their customers. Customers who feel satisfied over the service provided by an institution will increasingly trust the institution and will not turned to other institutions. The competition between sharia financial institutions in conducting their functions and objectives require these institutions to have at least three things; capital, technology and human resources or Sumber Daya Insani (SDI).

SDI is one of key factors in economic reformation, namely how to create high quality SDI with skills and high competitiveness in global competition which has been neglected so far. SDI is an important factor in life activity. The success of an organization or a company usually relies on the SDI. High quality SDI will affect the success of a company, and vice versa. In this context, human as the driving force of a company in building a successful company. The management created the strategy, goal, created innovation, and reaching company goal.

Islam encourages its followers to work of course their performance will incise their best value. Islam orders human to conduct production and development activity, either from quantity and quality, through utilize all their abilities diligently. Al-Qur'an states that the expanse of the earth is a potential which human persistence creates and develops it. Work productivity of a Muslim is reflected from their quantity and quality. In this matter it is described in Qur'an Surah (QS) An-Nahl: 65-69. Islam gives us the tools in the form of spirituality to make us more productive. Since productivity is not only about physical act, it also related to the condition of our mind, emotion, and soul. Someone who is at peace with their soul, heart and mind will be more productive compared with someone who is depressed.

However lately, people do not see Islam as a religion that encourages productivity. Some even calls it as a 'backward' religion and it makes people lazy and unproductive. This is emphasized through the publication of The Organization for Economic Co-operation and Development (OECD) about countries with the highest productivity. Of 15 (fifteen) highest countries, there is not one Islamic countries or countries with Muslim majority that have high productivity.

\section{Where Labor Productivity Is Highest}

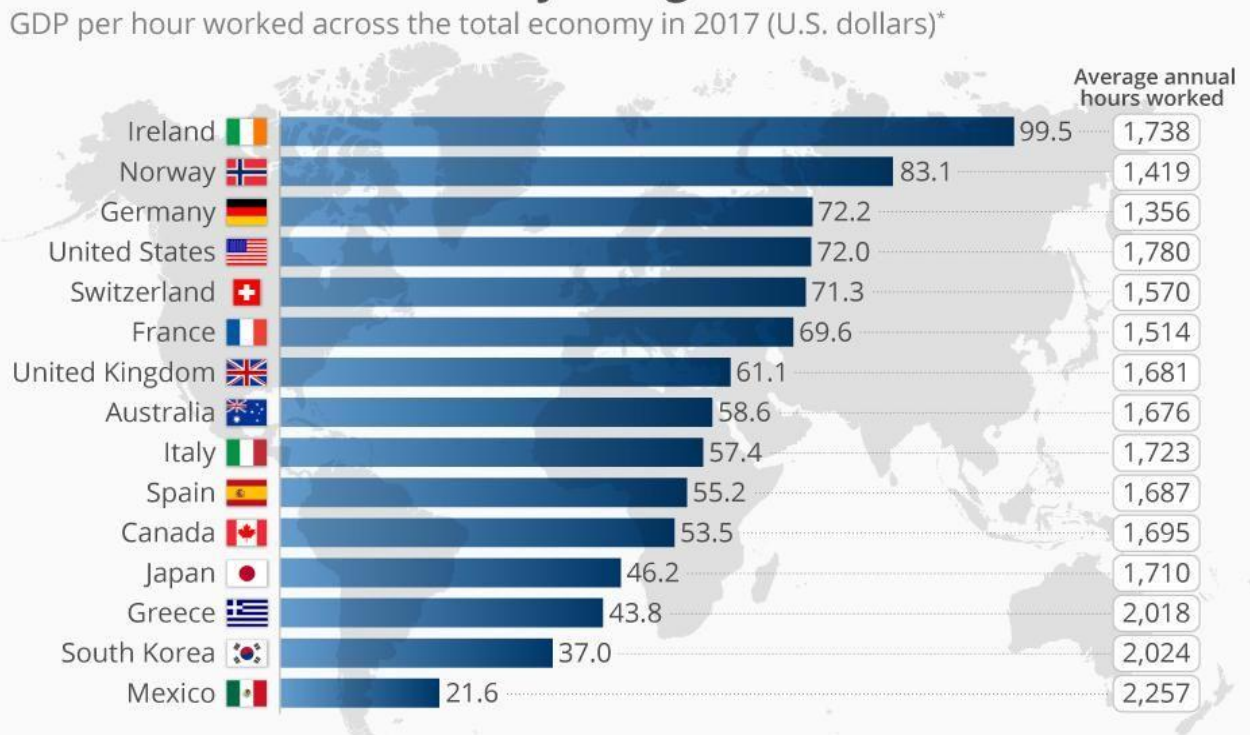

Figure 1. Info graphics of Countries with the Highest Labor Productivity in 2017

Source: www.forbes.com (2019) 
Based on the infographic in Figure 1, OECD use GDP per hour worked as a measure of employee productivity and measures how efficient employee input is combined with other production factors and used in the production process (McCarthy, 2019). Ireland is on the top of the scale with GDP per hour worked of $\$ 99.5$, followed by Norway with $\$ 83.1$ and Germany $\$ 72.2$. Interestingly, these top three countries have, on average, fewer annual working hours compared to other countries. However, despite the achievement of these 15 countries, this publication is a clear evidence that Islamic countries and countries with Muslim majority still unable to compete to be at the forefront of productivity, including Indonesia.

Based on the data released by Central Bureau of Statistics (BPS, 2019), it can be seen that employee productivity growth in Indonesia experiencing a fluctuating trend in the last 1 decade. Employee productivity of Indonesia indeed increases at 2.94\% in December 2019 compared to the $2.64 \%$ growth in the previous year. The data hits an all-time high of 5.56\% in December 2013 and the lowest is at $1.50 \%$ in December 2014. Central Bureau of Statistics provides real GDP in local currency based on SNA of 2008, with prices and employments of 2010. Employments are reported in yearly frequency that ends on August each year. Employments are not includes foreign nationals that work domestically. The Employee Productivity Growth prior to 2011 is calculated from real GDP based on SNA of 1993, with prices of 2000.

High employee productivity is every manager's desire in a company. However, it is not an easy task to increase the employee work productivity. Demanding employees continuously regardless of their condition is not a wise decision, but it can discourage employee or deteriorates their physical condition. Work productivity is the expected level of excellence and control of level of excellence to cater the customers' needs. Productivity starts at customers' needs and ends at customers' perceptions. This matter can be implemented on the interaction of employee and customer which includes timeliness, related to the speed of responding to customers' needs, the employees' appearance, related to cleanliness and suitability in dress, politeness and response to complaints, related to assistance provided to solve customers' problems. It means a good productivity can be seen from customers' perception not from company's perception. Customers' perception towards service productivity is a total assessment of the need for a product in the form of goods or services.

Employees are demanded to be able to conduct the task given more professionally, which means employees that have the view to always think, work hard, work full time, discipline, honest, have high loyalty and full of dedication for the success of their work. The management in a company always expects high employee work productivity. For that, it is necessary to have a leader who has the ability to manage the company by fostering and encourage awareness as well as advance work skill of the employees.

A culture is enabling people to see purpose synchronization and motivate them to a higher level, as shared values that made people feel good about the organization and their potential ability is genuine for the company. Company culture and value, organizational and managerial environment that came from that culture will highly influenced the best achievement outcome in the company. Empowerment, assertiveness, learning behavior, and teamwork are some of the attributes of strong organizational culture. Culture in this level is evident for superior employee productivity and a definite source of competitive advantage that will be very difficult for competitors to imitate. Alteration has an impact on changing organizational culture which inevitably has to face a series of adaptation. Management and utilization of finance also has to be sufficient to fund the government administration and regional development. Therefore the existing organizational culture needs to be improved so that it is expected to improve productivity. 
Vyas' (2017) research has found a strong relationship between organizational culture and employee work productivity in the pharmaceutical industry. According to him, indicators of organizational culture in the form of confrontation, trust, authenticity, and experimentation have a positive effect on employee productivity, while indicators of organizational culture in the form of openness, autonomy, proactivity, and collaboration have a negative effect on organizational culture. Other studies reveal similar findings, such as Mahdiyeh et al. (2016) which shows that organizational culture and its dimensions are positively correlated with employee productivity in the Iranian Ministry of Youth and Sports. According to Awadh and Alyahya (2013), a strong culture of an organization based on managers and leaders helps in increasing performance levels.

Provide motivation to employees in conducting their job means encourage awareness to employees to work optimally, so that organizational purpose will be easier to achieve. Someone who consciously involved in organization activity usually has certain background and motivation. Therefore, motivation is a thrust to move and motivation came from the word motive which means movers. So that the description of motivation can be said as a condition that moves or leads someone to conduct a certain act. The success of motivation result of someone highly influenced by resourced owned. The achievement of work motivation goal as is expected to create effectiveness, productivity, and efficient work result, either for the concerned individual or the organization.

Hairo and Martono's (2019) research has confirmed that employee motivation has a significant effect on employee productivity. Work motivation can spur employees to move their energy and thoughts in realizing company goals. Rusli (2020) proved that the intrinsic motivation and extrinsic motivation of employees at PT Permodalan Nasional Madani (Persero) Jakarta had a positive effect on employee performance. Not much different. In line with these findings, Ali et al. (2016) explored that motivation plays an important role on employee performance and job satisfaction in the IT Park (software house) sector in Peshawar, Pakistan.

\section{Literature Review}

\subsection{Work Productivity}

According to Sedarmayanti (2001) defines work productivity as how to create or improve the outcome of goods or services as high as possible by utilizing the resources efficiently. While according to Wibowo (2019) defines work productivity as the expected level of excellence and control over the level of excellence to fulfill customers' needs. Therefore it can be said that productivity is the level of excellence of a company by utilizing the human resources.

Good employee productivity in its turn will present good employee performance. According to Ricardo and Wade, productivity means ratio that represents volume of work done in a specific period, while performance is an indicator of productivity, consistency, and work quality. As the biggest Muslim country, Indonesia should be able to show the quality of its work force. Since mentally, Islam work ethic is an effort of sincere (ikhlas) to mobilized all the assets and thoughts to actualizing oneself as servants of God and as a part of the best society (khaira ummah). Those values actually should be present on the behavior of every Muslim in performing self-management and time at the performed worship. This is a very noble calling and full of moral messages, as stated by Agustian that the pillars of Islam from prayer rules are the efforts to build personal and social toughness in the service to God. The basic value of personal toughness is honesty, responsibility, visionary, discipline, teamwork, just and care. Followed by 6 (six) moral principles based on pillars of faith is to build Islam and emotional intelligence, in the hope to create ihsan heart (good deeds) that appreciated by God. This creates domino effect from mental 
revolution to encourage change, by building Islamic work ethic that drive organizational commitment and affects employee performance, and to maintain specified integrity.

\subsection{Organization Culture}

The daily life of society, it cannot be separated from the cultural ties that are created. Cultural ties are created by the concerned society, either in family, organization, business, or nation. Culture differentiates one society to the others in the way of interaction and act to finish the job. Culture ties the member of community groups in unity of view that creates uniformity in behavior or act. Over time, a culture should be formed in an organization and the benefits can also be felt in contributing to overall organizational effectiveness.

Organization culture refers to trust pattern, learned values and ways to overcome the experiences that have developed over the course of an organization's history, and tend to manifest in the material setting and in the behavior of its members (Hairo and Martono's, 2019). A success organization is an organization that has strong culture and that strong culture have to match with its environment (Rusli, 2020). Strong culture is characterized by the core value of the organization at large. The more members accept the core values, agree the level of importance and feel attached, the stronger the organization culture. Hence, adaptability is an important variable that important to note in describing the meaning of organization culture for the organization success.

\subsection{Work Motivation}

Motivation comes from the Latin word of "movere" that means drive or moving. Motivation is a condition or energy of an employee that makes the employee is able to implement certain purpose. Other definition, motivation is a thrust that makes the employee willing to do their job as good as possible by utilizing all the skill and expertise in conducting every task that become their responsibility, to achieve all the company's planned purposes.

\section{Methodology}

This study is conducted to all employees of Bank BJB Syariah Rancaekek Branch. Object used in this study covers all the available population of 18 respondents which are all the employees working at Bank BJB Syariah Rancaekek Branch. This study uses quantitative approach that tests the influence of Islamic entrepreneurship towards organizational commitment, and its implications towards organization performance. Data used are primary data that obtained from respondents through questionnaire. The questionnaire consists of questions related to the study variables with measurement scale of 5 (five) point Likert Scale. The questionnaire is divided into three main parts started from brief explanation regarding the purpose of survey, followed by major scale item measurement. The third part is used to measure the demographic profile of the participants, including age, gender, education level, income level, and marital status.

Data is screened and scanned to use valid case for data analysis. Structural Equation Modeling (SEM) using Partial Least Square (PLS) method is used to test measurements and structural models. The reliability and validity of the study construct is evaluated. The advantage of PLS is that it allows to make a structural modeling with small sample and no need for normal multivariate assumptions. PLS-SEM is a well-established technique that uses in various studies to estimate the path coefficient and investigate the complexity of relationship built in the structural modeling (Ali et al., 2018). SEM is a string statistic 
technique to define the measurement model and structural model (Nusair and Hua, 2010). The advantage of SEM method compared to path analysis method and multiple regressions is its better ability to predict that able to analyze to the deepest level of the variables or models being studied (Ulum et al., 2014). A. In other words, SEM is able to analyze a variable to its indicators that unable to reach by other analysis methods. The ability to connect the relationship between variable and efficiency in the examination of measurement model items are the two advantages compared to covariant based SEM. Figure 2 show the study model to see the relationship pattern of this study.

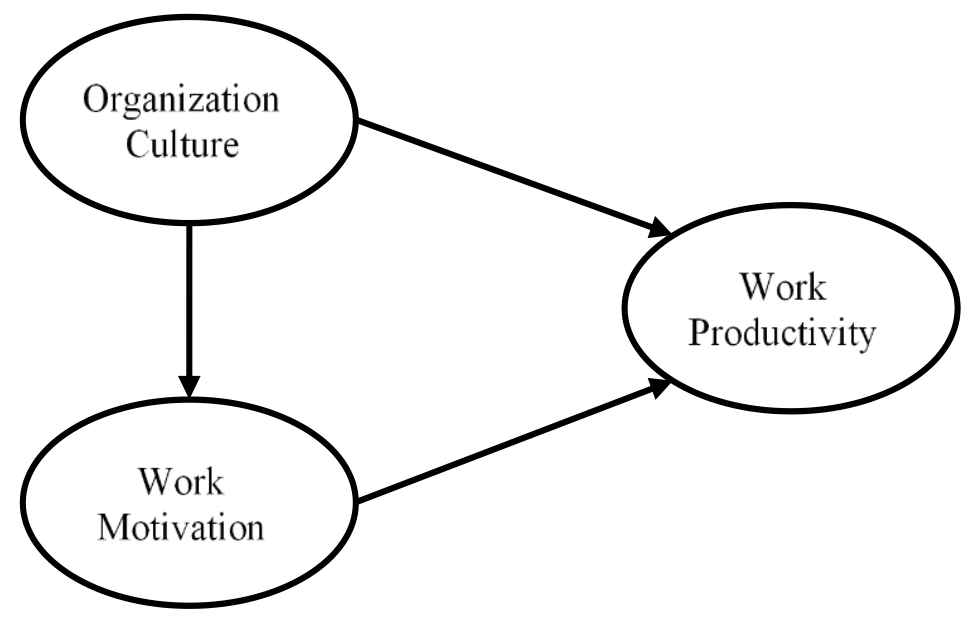

Figure 2. Research Model

\section{Results and Discussion}

The characteristics of the respondents observed in this study covers: gender, age, latest education, status, income, and length of work. The description of respondent's characteristics is served in Table 1.

Table 1. Respondent Demographics

\begin{tabular}{llcr}
\hline \multicolumn{1}{c}{ Variable } & \multicolumn{1}{c}{ Description } & Frequency & \% \\
\hline \multirow{2}{*}{ Gender } & Male & 8 & $44 \%$ \\
& Female & 10 & $56 \%$ \\
Age & < 30 year & 5 & $28 \%$ \\
& 30 - 40 year & 8 & $44 \%$ \\
Education & $>$ 40 year & 5 & $28 \%$ \\
& High school & 6 & $33 \%$ \\
Employee status & Diploma & 0 & $0 \%$ \\
& Bachelor & 12 & $67 \%$ \\
Income & Contract employees & 6 & $33 \%$ \\
& Permanent employee & 12 & $67 \%$ \\
& $<$ Rp 2,9 million & 6 & $33 \%$ \\
Length of work & Rp 2,9-4 million & 0 & $0 \%$ \\
& $>$ Rp4 million & 12 & $67 \%$ \\
& $<1$ year & 0 & $0 \%$ \\
& $1-3$ year & 2 & $11 \%$ \\
& $3-5$ year & 11 & $61 \%$ \\
\hline
\end{tabular}




\begin{tabular}{cccc}
\hline Variable & Description & Frequency & $\%$ \\
\hline & $>5$ year & 5 & $28 \%$ \\
\hline
\end{tabular}

Based on Table 1, it is known that the number of male respondents is 8 respondents or $44 \%$, while the number of female respondents is 10 respondents or $56 \%$; the majority of respondents are < 30 years old by 12 respondents or $67 \%$; the majority of respondents hold education level of S1 of 12 respondents or $67 \%$; the majority of respondents work as permanent employee by 12 respondents or $67 \%$; the majority of respondents have income of > IDR 4,000,000 by 12 respondents or 67\%; and the majority respondents have been working for 3-5 years by 11 respondents or $61 \%$.

\subsection{Measurement Model}

Next, to see the validity and reliability of the questionnaire instrument, Outer Loadings, Cronbach's Alpha and Composite Reliability (CR), and Average Variance Extracted (AVE) were used. The research results are presented in Table 2.

Table 2. Loading of the Item Measurement, Cronbach's Alpha, Composite Reliability dan AVE

\begin{tabular}{|c|c|c|c|c|}
\hline Item & Loading* & Cron-bach $\alpha$ & $\mathbf{C R}$ & AVE \\
\hline Organization Culture & & 0.798 & 0.858 & 0.713 \\
\hline - OC1 & 0.718 & & & \\
\hline$\cdot \mathrm{OC} 2$ & 0.830 & & & \\
\hline$\cdot \mathrm{OC} 3$ & 0.553 & & & \\
\hline$\cdot \mathrm{OC} 4$ & 0.709 & & & \\
\hline - OC6 & 0.838 & & & \\
\hline - OC7 & 0.577 & & & \\
\hline Work Motivation & & 0.862 & 0.901 & 0.805 \\
\hline - WM3 & 0.925 & & & \\
\hline - WM5 & 0.824 & & & \\
\hline • WM6 & 0.761 & & & \\
\hline • WM7 & 0.751 & & & \\
\hline - WM10 & 0.748 & & & \\
\hline Work Productivity & & 0.815 & 0.859 & 0.639 \\
\hline - WP1 & 0.675 & & & \\
\hline - WP2 & 0.570 & & & \\
\hline - WP3 & 0.559 & & & \\
\hline - WP4 & 0.588 & & & \\
\hline - WP6 & 0.652 & & & \\
\hline - WP8 & 0.758 & & & \\
\hline - WP9 & 0.764 & & & \\
\hline - WP11 & 0.589 & & & \\
\hline - WP12 & 0.552 & & & \\
\hline
\end{tabular}


Based on the examination presented in Table 2, it can be seen that the value of Outer Loadings for all indicators show the value above 0.5 so that all items are eligible to be the indicator of each latent variable. The value of AVE for all variables is above 0.5, of which organization culture is 0.713 ; work motivation is 0.805 ; and work productivity is 0.639 . Meanwhile, the value of Cronbach's Alpha for all variables is above 0.7 , of which organization culture is 0.798 ; work motivation is 0.862 ; and work productivity is 0.815 . Similar with the value of Composite Reliability (CR) that above 0.7 of which organization culture is 0.858 ; work motivation is 0.901 ; and work productivity is 0.859 , which means the result shows the consistency of each indicators to measure the construct.

\subsection{Structural Model}

To measure the geometrical average of the equation to be formed, check the Goodness of Fit (GoF) value. The values of R2 and Stone-Geisser Q2 also should be checked to assess how good the model in this study to be the predictor in PLS.

Tabel 3. Goodness of Fit (GoF) Index

\begin{tabular}{lccc}
\hline \multicolumn{1}{c}{ Variabel } & AVE & $\boldsymbol{R}^{\mathbf{2}}$ & $\mathbf{Q}^{\mathbf{2}}$ \\
\hline Organization Culture & 0.713 & & \\
Work Motivation & 0.805 & 0.393 & 0.355 \\
Work Productivity & 0.639 & 0.602 & 0.610 \\
Tenenhaus GoF (Goodness of Fit) & & 0.509 & \\
\hline
\end{tabular}

The standard to evaluate the result of GoF analysis is small (0.02), middle (0.25) and big (0.36). In this study, the value of GoF is 0.509 (see Table 3) that shows that the suggested relationship model performed relatively well and can be used as a good predictor as well.

To see how much the contribution of influence given by overall independent variable to dependent variable then it can be seen through $\mathrm{R}^{2}$. In this study, there are 2 (two) variables that can act as dependent variables, which are trust and loyalty. The value of R2 for work motivation is 0.393 or around $39.3 \%$, so that it can be concluded that the variable of organization culture observed can explain $39.3 \%$ of work productivity. The value of R2 for loyalty is 0.602 or around $60.2 \%$, so that it can be concluded that all independent variable observed can explain $60.2 \%$ of employee work productivity.

Table 4. Path Coefficient

\begin{tabular}{lcc}
\hline \multicolumn{1}{c}{ Path } & Coefficient & P Values \\
\hline Organization Culture => Work Motivation & 0.627 & $0.000 *$ \\
Organization Culture => Work Productivity & 0.602 & $0.000 *$ \\
Work Motivation => Work Productivity & 0.310 & 0.064 \\
Organization Culture => Work Motivation => Work Productivity & 0.194 & 0.102 \\
$*$ Significant at the 1\% level & & \\
\hline
\end{tabular}


Table 4 shows the relationship of every variable of the study. The result of examination states that: (i) organization culture influenced work motivation with a significant coefficient of 0.627 at $p$ value $<0.01$; (ii) organization culture influenced work productivity with a significant coefficient of 0.602 at $\mathrm{p}$ value $<$ 0.01 ; (iii) work motivation do not influence work productivity with an insignificant coefficient of 0.310 at $\mathrm{p}$ value $<0.01$ or 0.05 ; and organization culture do not influence work productivity through work motivation with an insignificant coefficient of 0.194 at $p$ value $>0.01$ or 0.05 .

\subsection{Discussion}

The organization culture that has been formed at Bank BJB Syariah Rancaekek Branch has become the identity of its employees and has become binding norms that are not visible to be kept running. Bank BJB Syariah Rancaekek Branch has successfully bring a good culture to be run by employees so that it can increase work motivation as well as increase their work productivity. The culture adopted by Bank BJB Syariah Rancaekek Branch may be inherited from the parent institution that has become the reference for all branch offices and sub-branch offices. However it does not rule out the possibility that the culture owned by Bank BJB Syariah Rancaekek Branch is only owned by them, which is the culture that become a characteristic and formed due to a long process. It is possible since culture is formed due to experiences. With a good culture, or course, it also has a good impact on employee motivation, which is increasing since the employees are considered to have strong reason as to why they are more excited and moved to work more. Furthermore, a good culture encourages employees to act more since they have strong reason to give more than they received.

\section{Conclussion}

This study has given empirical evidence at Bank BJB Syariah Rancaekek Branch that organization culture can significantly influence employee work motivation as well as employee work productivity. This gives the reason as to why the company should start to make a good culture pattern so that it can be implemented to all personnel in the company. A good organization culture, of course, will give a characteristic that can make all stakeholders in the company proud. The implementation of organization culture must be conducted immediately by the company since the process of forming a culture cannot be done instantly, because it has to go through a long process and mature experience.

The result of this study is expected to be the beacon for the managers in the company to pay attention to small habits existed in the company. Moreover, it is expected that this study can give scientific contribution to next researchers to use the result of this study as a reference and keep developing the research in the field of organization culture, employee work motivation, and work productivity.

\section{References}

Ali, A., Bin, L. Z., Piang, H. J., \& Ali, Z. (2016). The impact of motivation on the employee performance and job satisfaction in it park (software house) sector of Peshawar, Pakistan. International Journal of Academic Research in Business and Social Sciences, 6(9), 297-310.

Ali, H, \& Miftahurrohman, (2015), Analisis Pengaruh Dana Pihak Ketiga, Tingkat Bagi Hasil, Non Performing Financing Dan Profitabilitas Terhadap Volume Pembiayaan Berbasis Bagi Hasil Pada Perbankan Syariah Di Indonesia, J. Tauhidinomics, 1(2), 151-166. 
Ali, F., Rasoolimanesh, S. M., Sarstedt, M., Ringle, C. M., \& Ryu, K. (2018). An assessment of the use of partial least squares structural equation modeling (PLS-SEM) in hospitality research. International Journal of Contemporary Hospitality Management, 30(1), 514-538.

Awadh, A. M., \& Alyahya, M. S. (2013). Impact of organizational culture on employee performance. International review of management and business research, 2(1), 168-175.

Badan Pusat Statistik, "Produk Domestik Regional Bruto Provinsi-provinsi di Indonesia Menurut Lapangan Usaha 2014-2018,” Badan Pusat Statistik, Report 9302001, 2019.

Hairo, A. M., \& Martono, S. (2019). The Effect of Environment, Training, Motivation, and Satisfaction on Work Productivity. Management Analysis Journal, 8(1), 50-57.

Mahdiyeh, M., Nakhaei, H., \& Kebriaei, A. (2016). Impact of Organizational Culture on Productivity: A Study among Employees of Ministry of Youth and Sports, Iran. International Journal of Humanities and Cultural Studies (IJHCS) ISSN 2356-5926, 3(3), 170-177.

McCarthy, N., Where Labor Productivity Is Highest [Infographic], Forbes, 2019. https://www.forbes.com/sites/niallmccarthy/2019/02/05/where-labor-productivity-is-highestinfographic/\#40e07115ea44 (accessed Sep. 28, 2020).

Nusair, K., \& Hua, N. (2010). Comparative assessment of structural equation modeling and multiple regression research methodologies: E-commerce context. Tourism Management, 31(3), 314-324.

Rusli, A. K. (2020). The Effect of Work Motivation Toward Employee Performance at PT. Permodalan Nasional Madani (Persero) Jakarta. Jurnal Ilmu Sosial Politik Dan Humaniora, 3(1), 1-12.

Sedarmayanti, (2001), Sumber Daya Manusia dan Produktivitas Kerja. Jakarta: Mandar Maju.

Suhartanto, D., Farhani, N. H., \& Muflih, M. (2018). Loyalty Intention towards Islamic Bank: The Role of Religiosity, Image, and Trust. International Journal of Economics \& Management, 12(1), 137-151.

Suhartanto, D., Gan, C., Sarah, I. S., \& Setiawan, S. (2019). Loyalty towards Islamic banking: service quality, emotional or religious driven?. Journal of Islamic Marketing, 11(1), 66-80.

Ulum, M., Tirta, I. M., \& Anggraeni, D. (2014). Analisis Structural Equation Modeling (SEM) untuk Sampel Kecil dengan Pendekatan Partial Least Square (PLS). Prosiding Seminar Nasional Matematika, Universitas Jember, 19 November 2014.

Vyas, S. Organization Culture and Employee's Productivity “A Study of Pharmaceutical Industry”. International Journal of Research and Scientific Innovation. 4(1), 15-20.

Wibowo, (2019), Manajemen Kinerja, 5th ed. Jakarta: Raja Grafindo Persada. 